Vol. 3 No. 1

Juni 2021

e- ISSN 2685 - 0559

p- ISSN 2684 - 673X

\title{
THE PENOMENON OF APARTHEID TOWARD AFRICAN PEOPLE IN "ESCAPE FROM PRETORIA": HISTORICAL APPROACH
}

\author{
Pijar Omar Piscesco ${ }^{1}$ \\ Universitas Putera Batam (UPB), Batam, Indonesia \\ pb181210029@upbatam.ac.id \\ Tomi Arianto ${ }^{2}$ \\ Universitas Putera Batam (UPB), Batam, Indonesia \\ Tomi.arianto@puterabatam.ac.id
}

\begin{abstract}
The purpose of this research is to reveal how the phenomenon of breaking the practice of apartheid construction toward the black race in the escape from Pretoria movie. The construction of apartheid has placed the black race under the domination of the white race and this behavior is legitimate in the everyday life of society. The dichotomy that places the black race as an inferior race has become a normal habit in society. By using a historical approach, the researchers revealed how the apartheid construction was exposed through the black racial figures in the movie. Qualitative descriptions with historical approach analysis techniques were used as the method in this study. The results of this study reveal: the first, the apartheid construction phenomenon that occurred in the movie. The second is the efforts by breaking the apartheid construction from in movie. The phenomena found related to the construction of apartheid in the movie include: 1) the paradigm of society that perceives whites to be better than blacks, 2) racism. Breaking the habits is revealed through the character Tim Jenkin by changing the paradigm of thinking of the white race after escaping from a Pretoria prison.
\end{abstract}

Keywords: Apartheid, Racism, Prison and Movie

\section{INTRODUCTION}

Racism is a phenomenon that has existed for a long time and has had various negative effects over time. Apartheid is also part of racism which still imposes a practice similar to slavery in various parts of life based on different characteristics, such as race. According to Jones (2000), apartheid is a condition where a group of people is 
Vol. 3 No. 1

Juni 2021

e- ISSN 2685 - 0559

respectively segregated and categorized in individual by their race. It can be concluded that apartheid is similar with the racism and it still a violation of human rights.

Racism is not only happened in a country with a majority of white race. In Africa itself, racism has ever happened in the 1970s. Nelson Mandela was a politician and also someone who liberated the African people from apartheid. According to Anyaoku (2000), she stated that "in 1994 elections were the key that unlocked the door to a new, nonracial future for South Africa, Mandela's inauguration as President, on 10 May, was an extraordinary occasion, alive with symbolism, full of emotion and infused with joy and hope. An opportunity wrapped in a challenge; for, having fought and given no quarter to the apartheid regime over the years, the Commonwealth now had to persuade the self-same government of its ability to play the role as honest broker in the planned negotiations with the African National Congress". From the citation above, it can be concluded that the racism had happened in Africa. To get escape from this regime, many various mediations were carried out to end apartheid itself and Nelson Mandela used negotiations as the mediation.

The concept of existential behavior racism can also be used as a tool to dissect the construction of apartheid. The effort of breaking the habits in society according to existential behavior racism is the image of the black race. Where often there are differences in different treatments experienced by them. Apart from receiving different treatment, their race also does not receive justice in human rights.

One of the stories that reveal the apartheid phenomenon and the attempt to break the habit is in the movie Escape from Pretoria. This movie tells of two vocal youths, Tim Jenkin (Daniel Radcliffe) and Stephen Lee (Daniel Webber), who actively opposes the practice of Apartheid in South Africa Apartheid, is an understanding that considers the white race to be in a higher position than the black race. Once while distributing leaflets containing the Anti-Apartheid campaign, they were caught by the police. Jenkin and Lee were found guilty by the court and sentenced to 12 and 8 years in prison, respectively. Then, they were taken to the Pretoria prison, a high-security prison where political prisoners were exiled.

In this prison they met another political prisoner who was sentenced to life in prison named Denis Goldberg (Ian Hart). Jenkin and Lee invite Goldberg to work together to escape but he refuses. They then invite another prisoner, Leonard Fontaine (Mark Leonard Winter) to work together to plan an escape. This time Fontaine agreed and they immediately started the action by analyzing the security of the prison and making a wooden key to open the cell door. But, they make lots of keys because each cell 
Vol. 3 No. 1

Juni 2021

e- ISSN 2685 - 0559

door has a different key. In the end they managed to open all the doors in the Pretoria prison, and they managed to get out of prison. After leaving pretoeia they resumed their politicization until the apartheid regime was successfully lifted from Africa as Nelson Mandela became the president in Africa.

Apart from this research, there are several articles that have contributed to the development of this research idea. The first article was written by Anyaoku (2000). She analyzed the methods and historical approaches based on real events. In contrast to what Anyaoku wrote, researchers used a movie as material for analysis. Farbsteins (2020) article also contributed in developing this research idea. The article that Farbstein has wrote about the results of an analysis of apartheid. There are similarities between the author and Farbstein's article, where the author also analyzes based on the perspective of each character. What distinguishes the author from Susan H. Farbstein's article is the source used. Where Articles Susan H. Farbstein get the sources used are from a practitioner, while the writer is based on a movie.

\section{THEORETICAL REVIEW}

2.1. The historical approach The historical approach is a way to place oneself in space and time in the history of human civilization. The method is none other than by studying history as a whole, not divided by political and religious boundaries, even time constraints. With this it is hoped that we can develop a sense of "belonging and being human". According to Wodak \& Meyer (2001), historical approach is General social theory, indebted to critical theory, plays a marginal position in contrast with the aforementioned discourse model and historical analysis: meaning is understood predominantly historically. It can be concluded that in the field of politics, the historical approach finds its focal point in attempting to establish conceptual structures for political debate.

This research is related with the literature. The word literature itself was taken from French word "Lltterature". French also adopted it from Latin word "Litteratura" and Greek word "Liter $a$ "which mean letter or alphabet. Literature is related to tex and we have to know some basic ter $\mathrm{m}$ on text. The word "Text" adopted from French word "Texte" and Latin "Textus" which is mean tissue. According to Wellek \& Warren (1948) "One way is to define literature is as everything that in print". From the explanation, we can conclude that literature, as its medium language, is a social institution, a social development. In their very essence, such typical literary devices as symbolism and meters are social. They are conventions and standards that could only have been established in society.

From the introduction, we know that apartheid is a condition 
Vol. 3 No. 1

Juni 2021

e- ISSN 2685 - 0559

where a group of people is respectively segregated and categorized in individual by their race. In apartheid-era, many violations of human right that particularly the position of corporate actors. The complainants and the legal team 7worked collaboratively in the implementation of a group lawyering strategy so that decisionmaking in the case could be more collectively shared by who would be part of it, what claims and arguments would be raised, how and when the case would continue. We succeeded in reshaping public views of the case through the joint efforts of both the plaintiffs and the legal team, making it clear that it was not an attempted end-run around the truth and reconciliation phase of South Africa, but rather a genuine initiative by survivors seeking remedies for past damages. It was always about the people involved in the Apartheid litigation, about what they had suffered and survived, and about their quest for justice. As a consequence, we litigated in service of goals beyond just a liability judgment, with storytelling prominent among our goals. When the case was eventually dismissed before reaching trial, I felt tremendous sorrow about the fairly small opportunities for the plaintiffs to tell a larger audience their stories.

\subsection{Previous Study}

Research on racism, discrimination or dichotomy based on skin color has certainly been widely studied. In this context, the researcher focuses on the apartheid phenomenon which has become a deep wound for Africans who feel they are not humanized. In this study, of course, researchers get various inspirations from readings and literature reviews from related journals. The development of this idea still follows existing scientific procedures so that it remains different from previous studies.

The first article that contributed significantly to this research was written by Daulay, R., \& Arianto, T. (2020) who analyzed the story of the collapse of our surau. Specifically, this article does not discuss Africanism, but the postcolonial discourse that has been criticized is sufficient to generate the idea of this research. Post-colonial discourse has also played a major role in influencing the legitimacy of the dichotomy of race and skin color. Racism and discrimination will of course also arise from this.

Waworuntu \& Arianto (2019) also analyzed a research with a postcolonial approach in their article published in the BASIS journal. In contrast to previous research, cultural identity in this study is the cause of the emergence of the racial dichotomy and its systematic legitimacy. Of course, this research can be a reference in the context of racial discrimination and identification based on identity.

The last research was conducted by Supriadi, M. N. (2021) who analyzed the Historical Approach in Bible Interpretation. The substance of the Bible verse can 
Vol. 3 No. 1

Juni 2021

e- ISSN 2685 - 0559

p- ISSN 2684 - 673X

be understood by analyzing it until it finds the eternal and universal principle of a verse. The interpretation of Bible verses is only on finding the meaning of the past and present context, causing problems in terms of substance.

\section{METHOD}

The writer used the qualitative method in analyzing the movie Escape from Pretoria. According to Tracy (2007), she said that the phrase qualitative methods is an umbrella concept that involves interviews (group or one-on-one), observation of participants (in person or online), and review of records (paper or electronic). These approaches may include field study, a focus-group space, an office, or a classroom. By design, qualitative approaches need not include longterm immersion in a community or include a systematic analysis of all social practices. Some qualitative studies, in fact, span the duration of a single day.

According to Taylor, Bogdan, \& DeVault (2016), said that Qualitative researchers are concerned with the sense of their lives that connect to things and knowing people from their own reference frames and observing life as they perceive it is central to the phenomenological viewpoint and therefore qualitative study. From it, we can conclude that. In order to understand how those people see things, qualitative researchers empathize and connect with the people they study.

\section{RESULT AND DISCUSSION}

Escape from Pretoria was released in 2020. The movie is based on the true story that happened in 1970s. The movie also played with some famous actors Daniel Radcliffe, Daniel Webber, Ian Hart, and Mark Leonard Winter. In the movie, it also consists of apartheid construction. The construction was showed from the way the movie described the situation. Then the writer analyzed the apartheid construction based on the perspective from the movie.

\section{A. The Beginning of the Movie}

\section{Scene 1}

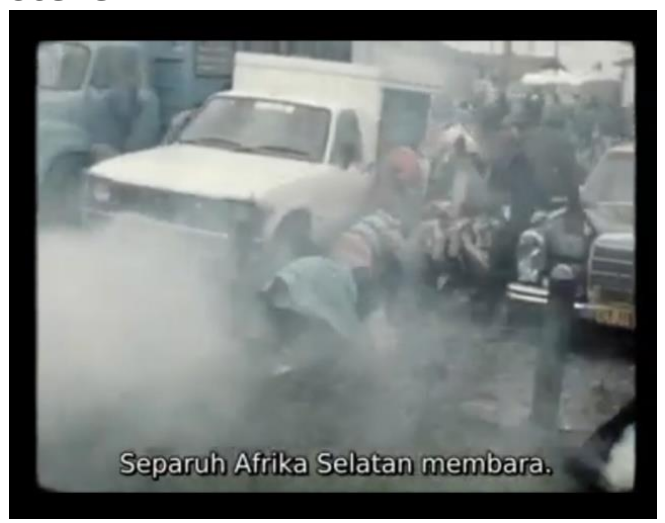

In the beginning of the movie, it already describe how the situation in the South Africa. The scene told that half of South Africa is burning. We can take the conclusion that the situation in movie is already chaos.

Scene 2

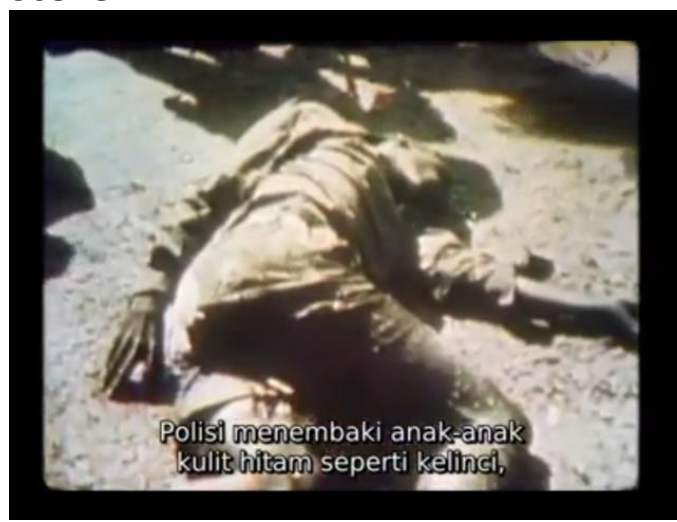


Vol. 3 No. 1

Juni 2021

e- ISSN 2685 - 0559

In second scene, it showed the carnage that happened to the black race. The word "rabbit" it tells like the black race was be in the same position with animals.

\section{Scene 3}

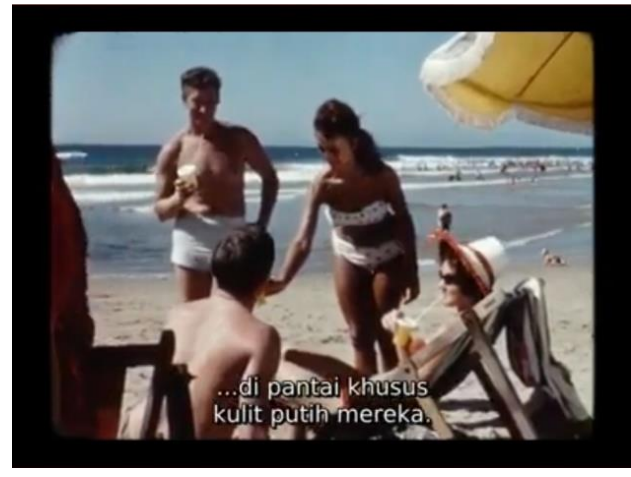

In the third scene, it showed the different treatment between the white race and the black race. The white race seems like freedom enjoying the day and has no problem with the economic condition while the black race struggle with the poverty.

\section{Scene 4}

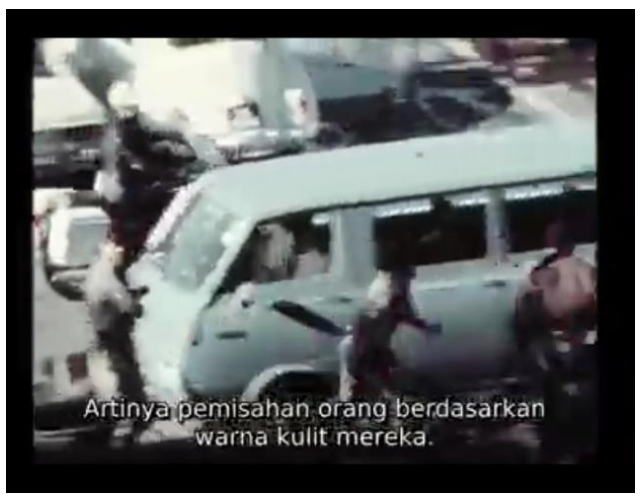

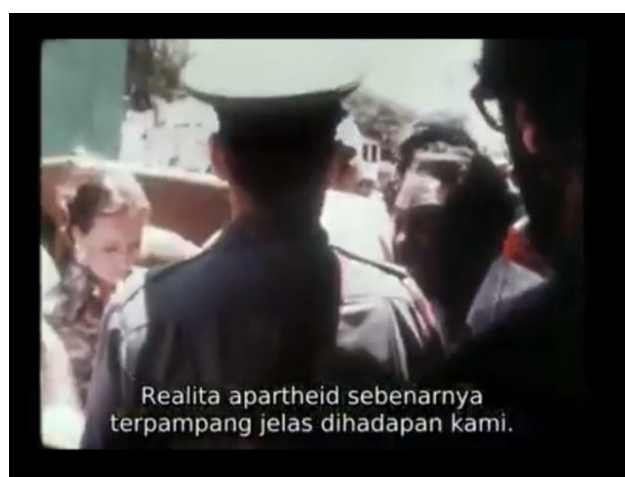

Then at the fourth scene at the beginning in the movie, showed that the apartheid regime it's already happened.

\section{Scene 5}

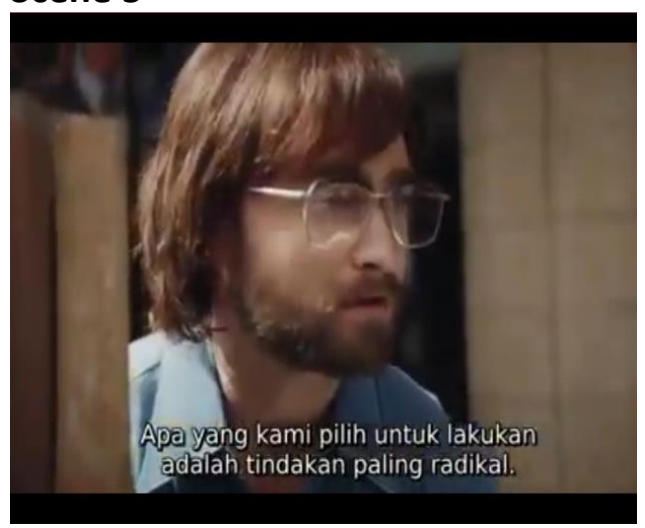

At the fifth scene, it showed the main character was a white race that refused the apartheid regime. It can be seen from this following scene.

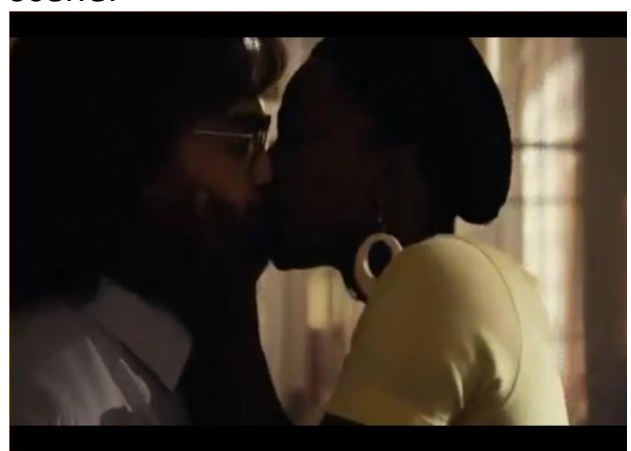

Where the scene told that the main character was married with the black race woman. 
Vol. 3 No. 1

Juni 2021

e- ISSN 2685 - 0559

Jurnal

\section{B. The Action of Apartheid}

\section{Scene 1}

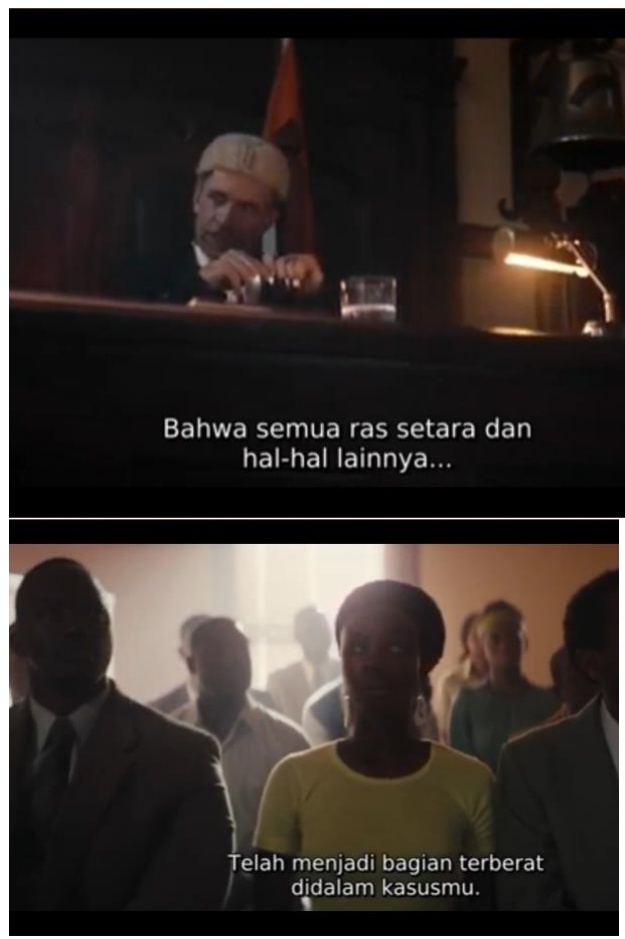

At the first scene we can see that the law from the movie was refused the existence of racial equality. The attorney stated that equalizing all races is a serious offense. It can be concluded that the law only side to white race.

\section{Scene 2}

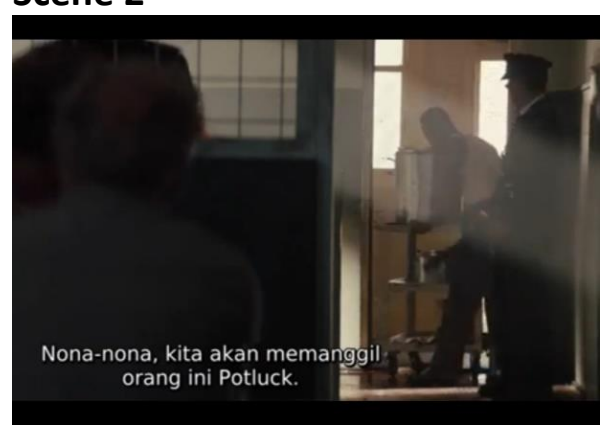

Then at the second scene, we can see the prison guard humiliate the prisoner who is the black race by making fun of him.

\section{B. The Fall of Apartheid}

Scene 1

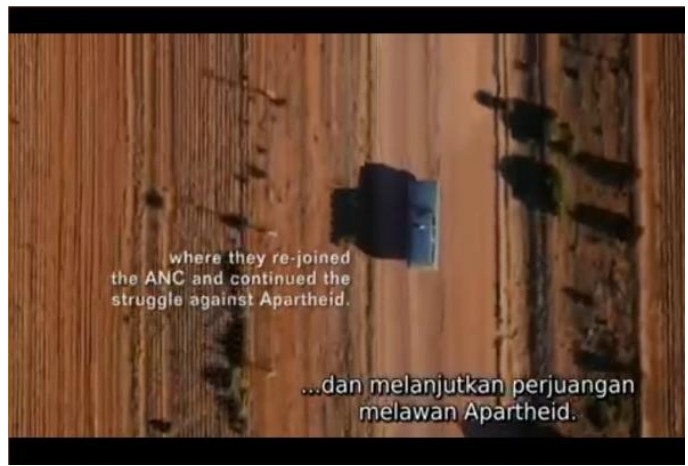

The first scene told that after they were escape from the prison, they continued their struggle to fight the apartheid.

\section{Scene 2}

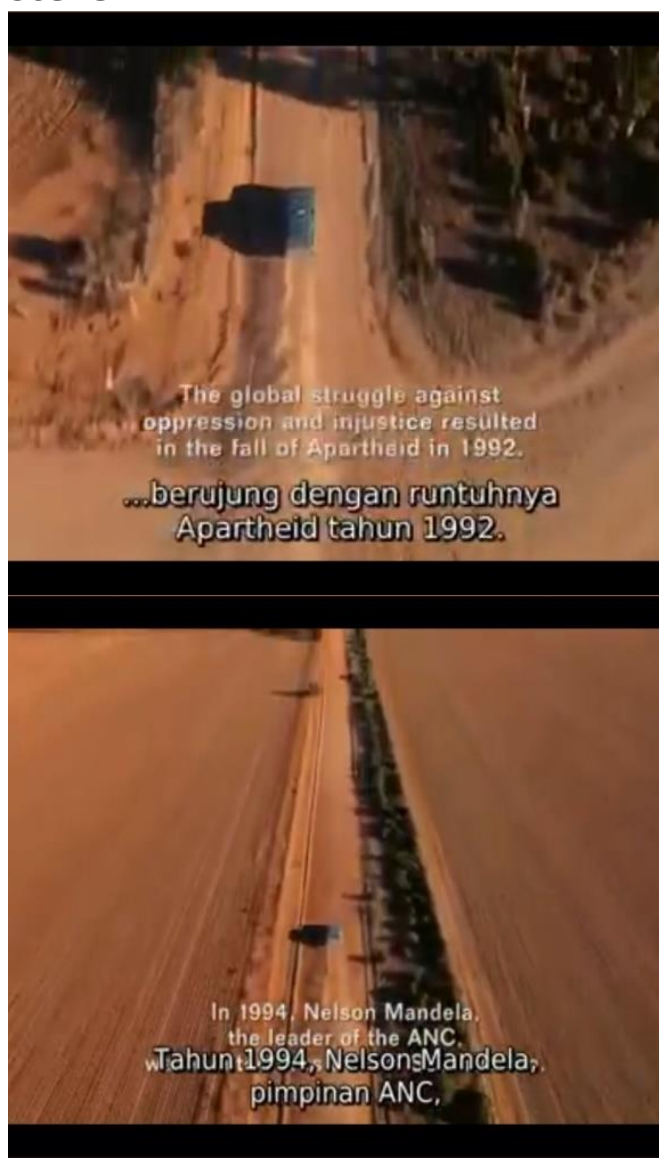


Vol. 3 No. 1

Juni 2021

e- ISSN 2685 - 0559

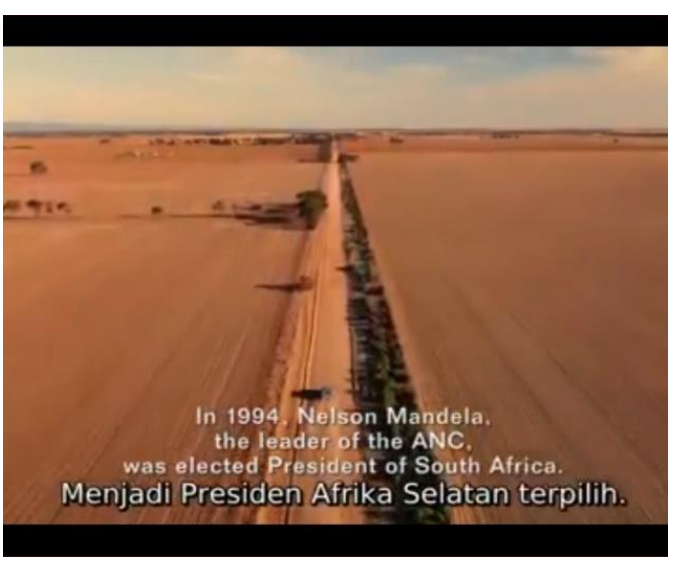

Then at the second scene, it told that the apartheid regime was already fallen in 1992 as selected Nelson Mandela as the President of South Africa.

\section{CONCLUSION}

The movie Escape from Pretoria give us a view how the apartheid regime happened in South Africa. The movie was taken in 1970s, where the racism still exists. The entire scene was running smoothly give the viewer the perspective about the situation that happened in the story. Then the plot is also not difficult to understand. The movie also gave the massage about how bad the racism is. Beside of the view of the movie, there is also some scenery that we can use as the object of the analysis. The story how the apartheid construction happened and ended was included in the movie.

\section{REFERENCES}

Anyaoku, E. (2000). The Commonwealth, Mandela and the Death of Apartheid. Nigeria: The Round Table Ltd.

Daulay, R., \& Arianto, T. (2020). The Construction of Postcolonial
Discourse In The Story Robohnya Surau Kami By A. A. Navis. Idebahasa, 2(1), 13-26. Https://Doi.Org/10.37296/Ideb ahasa.V2i1.36

Farbsteins, S. H. (2020). Perspectives From a Practitioner: Lessons Learned From the Apartheid Litigation. Massachusetts: Harvard International Law Journal.

Jones, T. F. (2000). Contradictions and Constructions: Psychiatric Perceptions in Apartheid South A frica, 1948-1979. Canada: National Library of Canada.

Supriadi, M. N. (2021). Pendekatan Sejarah Penebusan dalam Penafsiran Alkitab: The Redemptive-Historical Approach in Bible Interpretation. PASCA: Jurnal Teologi Dan Pendidikan Agama Kristen, 17(1), 18-29. https://doi.org/10.46494/psc.v1 7i1.136

Taylor, S. J., Bogdan, R. and DeVault, M. L. (2016). Introduction to Qualitative Research Methods. New Jersey: John Wiley\& Sons.

Tracy, S. J. (2007). Qualitative ReseaRch Methods. New Jersey: John Wiley \& Sons.

Waworuntu, Michelle Intan Goh Rumengan; Arianto, Tomi. Hibridity of the Chacracters in My Son The Fanatic Story by Hanief Kureshi. Jurnal Basis, [S.I.], v. 6, n. 2, p. 197-208, oct. 2019. ISSN 2527-8835. Available at: <http://ejournal.upbatam.ac.id /index.php/basis/article/view/1 432>. 
Vol. 3 No. 1

Juni 2021

e- ISSN 2685 - 0559

Wellek, R. and Warren, A. (1948).

Theory of Literature. New York:

HARCOURT, BRACE AND

COMPANY.

Wodak, R. and Meyer, M. (2001). methods of critical discourse

analysis. london: sage

publications. 
Vol. 3 No. 1

Juni 2021

e- ISSN 2685 - 0559

p- ISSN 2684 - 673X
Jurnal

IdeBahasa

Impirasi Dosen Babasa dan Sastra 